\title{
DEMOGRAPHIC ENDANGERMENT OF THE RURAL SETTLEMENTS OF ROGOZNA MOUNTAIN AND POSSIBILITIES FOR THEIR REVITALIZATION
}

\author{
Mila Pavlović ${ }^{* 1}$ \\ "University of Belgrade - Faculty of Geography, Belgrade
}

\begin{abstract}
The study of the rural areas of Serbia is in the narrowest sphere of interest of the economic policy makers, with the aim of creating more balanced regional development. The economic underdevelopment of rural areas is a burden on the state as a whole, and one of the most important development issue. Based on the results of the 2002 and 2011 census, it can be concluded that the number of inhabitants in Serbia is reduced by 30,000 annually. Particularly worrying is the fact that the balance between rural and urban areas has been disturbed, at the expense of rural areas. The data show that out of 4,709 villages in Serbia, 700 of them have no demographic future. Abandoned houses, collapsed cooperative homes, shops, empty schools, closed ambulances - all of these are indicators of the seriousness of the problems that the mountain villages of Serbia, and therefore Rogozne, are facing. The situation in rural areas in Serbia may be best illustrated by the following: 1,200 villages are in a phase of disappearance, 50,000 houses are empty, and in another 150,000 no one currently lives, more than 1000 villages have fewer than 100 inhabitants. However, the most important problem is the average age of people living in the villages of Serbia - 43.6 years, while the average age of citizens in cities is 41.3 years. The residents of rural areas on Rogozna mountain consider that, should the economic situation improve, it should encourage positive demographic changes in these villages. This is only possible through ensuring a secure existence and sustainable agricultaral production (secure placement of agricultural products).
\end{abstract}

Key words: emigration, rural areas, depopulation, agriculture, Rogozna.

${ }^{1}$ Corresponding author: M. Pavlović, University of Belgrade - Faculty of Geography, Studentski trg 3/III, 11,000 Belgrade, Serbia; e-mail: mila.pavlovic2@gmail.com 


\section{Introduction}

There are numerous authors who have studied the problem of rural development and possibilities for revitalization of rural areas: Павловић, 2016; Павловић et al., 2015; Sobczyk, 2014; Esparcia, 2014; Galdeano-Gomez et al., 2010; Павловић and Мишовић, 2012; Павловић 2009; Buchenrieder et al., 2007; Murdoch, 2000; Lowe, et al., 1995.

Mountain Rogozna is located in the southwestern part of Serbia, in Raška region, bordered by the valleys of the river Raška and the upper and middle valley of the Ibar river. On the Rogozna mountain (not including the territory of Autonomous Province of Kosovo and Metohija) there are 58 villages, where according to the 2011 census there were 21,279 inhabitants. The settlements which were included in this paper are administratively classified into 15 local communities. According to the 2011 census, the average area of the settlement is 719.31 ha, with an average of 366.88 inhabitants per settlement, and an average population density of 51 resident per square kilometer.

The etymology of the mountain and the microregion is also interesting. It is a mountainous region with settlements at an absolute height of up to $1,000 \mathrm{~m}$. From historacal sources it can be seen that the name Rogozna was only refered to the east part of this mountain. That name in the 18th century was extended to the western part of the mountain. The name originated in the eastern part of the mountain massif, where there are plenty of abandoned old mining shafts. In these places water is retained and the shallow ponds were formed, There areas are habitat for Typha (Typha latifolia) or in Serbian "rogoz". The significance of this plant in the past was much larger than it is today. The confirmation for this claim we find in historical sources, for example the Great Prince of Serbia Stefan Nemanja has asked for his final resting place to be made out of typha ('һоровић, 1928). Based on scientific facts, it is clear that the name of the mountain was first formed, and then the name for the entire region.

The name Rogozno was recorded around 1316, in the charter for Banjska Monastery (Петровић, 2010). In the letter of Pope Benedict to the Ninth Archbishop Marin of the city of Bar in 1303, there is the oldest written record of the name "Rogozno". In 1316, King Milutin donated the area of mountain Rogozna to the monastery of Banjska. This name refers to the same mountain in the $14^{\text {th }}$ century, as well as in the $16^{\text {th }}$ and $17^{\text {th }}$ centuries (Петровић, 2010). Before the $18^{\text {th }}$ century the western half of the mountain, however was known under different names. 


\section{Main factors of revitalization of rural areas in Rogozna}

One of the most important factors for the revitalization of rural areas is the traffic connection. Lack of roads and poor traffic connections with regional centers was one of the main reasons for the intensive emigration of population from Rogozna. Bearing in mind that this is mostly a mountainous region and it consists of small but deep river valleys, the construction of the traffic network is conditioned by the morphology of the terrain. Natural factors have caused access to this area to be difficult and that it is isolated.

However, during the Middle Ages, many important roads were cross over Rogozna mountain. The routes of many roads are still visible today. A famous caravan road passed through this area, connecting Bosnia with Skopje and Thessaloniki. This road route had main role in all commercial trade until the construction of the railway in the valley of Ibar, when the town of Raška took over the main role in loading and unloading goods for this part of Serbia. On this caravan road, during the Middle Ages, there was also a mining town called Rogozno, inhabited by Saxons miners and traders from the city of Dubrovnik.

The modern road network that connects this part of Serbia has succeeded the routes of these old roads, to a great extent. This is also the case with the internal road network within the region.

Table 1 - Basic indicators of the road network in the territory of the municipalities of Novi Pazar, Tutin and Raška (in km)

\begin{tabular}{|c|c|c|c|c|c|c|c|c|c|}
\hline \multirow{2}{*}{ Year. } & \multirow{2}{*}{ Municipality } & \multirow{2}{*}{ Total } & \multirow{2}{*}{$\begin{array}{l}\text { Modern } \\
\text { roads }\end{array}$} & \multicolumn{2}{|c|}{$\begin{array}{l}\text { State roads, } \\
\text { class Ib }\end{array}$} & \multicolumn{2}{|c|}{$\begin{array}{l}\text { State roads, } \\
\text { class IIa }\end{array}$} & \multicolumn{2}{|c|}{$\begin{array}{l}\text { Municipal } \\
\text { roads }\end{array}$} \\
\hline & & & & All & $\begin{array}{c}\text { Modern } \\
\text { roads }\end{array}$ & All & $\begin{array}{c}\text { Modern } \\
\text { roads }\end{array}$ & All & $\begin{array}{c}\text { Modern } \\
\text { roads }\end{array}$ \\
\hline \multirow{3}{*}{1981} & Novi Pazar & 689 & 177 & 73 & 73 & 89 & 46 & 527 & 58 \\
\hline & Tutin & 220 & 43 & 26 & 26 & 154 & 17 & 40 & - \\
\hline & Raška & 488 & 109 & 65 & 65 & 119 & 34 & 304 & 10 \\
\hline \multirow{3}{*}{2001} & Novi Pazar & 740 & 135 & 58 & 58 & 99 & 41 & 583 & 36 \\
\hline & Tutin & 528 & 81 & 32 & 32 & 102 & 40 & 394 & 9 \\
\hline & Raška & 536 & 192 & 55 & 55 & 113 & 70 & 368 & 67 \\
\hline \multirow{3}{*}{2014} & Novi Pazar & 756 & 216 & 61 & 61 & 112 & 77 & 582 & 78 \\
\hline & Tutin & 824 & 160 & 32 & 32 & 94 & 82 & 696 & 46 \\
\hline & Raška & 554 & 310 & 39 & 39 & 121 & 118 & 395 & 153 \\
\hline
\end{tabular}

Source: Општине у Србији, 1982, 2002, 2015, Републички завод за статистику. 
The data in Table 1 best illustrate the state of the road network in the territories of the municipalities of Novi Pazar, Tutin and Raška from 1981 to 2014. The road network consists of the state roads class Ib, class IIa and the municipal roads. Their total length is $2,134 \mathrm{~km}$, of which $132 \mathrm{~km}(6.2 \%)$ are state roads class $\mathrm{Ib}$ and $327 \mathrm{~km}(15.3 \%)$ are state roads class IIa. The largest length of $1,673 \mathrm{~km}$ and the biggest relative share of $78,4 \%$ in the road network have municipal and unclassified roads.

In the period from 1981 to 2014, the local government has made a significant effort to improve the road network. Best example is the fact that in 1981, total length of roads was 1,397 km. In 2014, the length of the roads was increased by $52,8 \%$. This increase was accompanied by a partial modernization of the roads. Namely, the length of roads witf the modern roadway from $1981(329 \mathrm{~km})$ to $2014(686 \mathrm{~km})$ is more than doubled $(108.5 \%)$. All state roads class $\mathrm{Ib}$ had modern roadway during the observed period. However, the roads in the rural areas are a major problem. The roads with modern roadway leads to the village, but the inner road network consists of macadam roads. These roads have been rehabilitated in some villages, and are mostly in extremely poor condition. In some villages the local residents have financed themselves the construction of moders roads. The funds were mainly allocated by residents who are on temporary work abroad.

Poor infrastructure in the villages of Rogozna, caused an intensive process of emigration and depopulation. The residents in these villages, besides the bad road network, are also faced with a lack of water supply and the existence of several small water supply systems with difficulty in applying hygienic and sanitary measures. The problem is also an inadequate electrical network, which is very unstable, as indicated by the large number of malfunction in household appliances. Despite the fact that many villages do not have a sewage network, nor waste disposal from utility services, there are no landfills that would represent a significant environmental problem.

The demographic processes in the rural areas of Rogozna mountain are best illustrated by population change and the population size of rural settlements. Several factors have influenced on demographic changes. The most important factors are: degree of economic development, process of urbanization, natural increase of population and migration, especially the migration between rural and urban areas. Due to the intensive emigration, the number of inhabitants of this region has varied considerably during the past. 

and Possibilities for their Revitalization

Table 2 - Hypsometric location of rural settlements and rural population of Rogozna in 1981 and 2011

\begin{tabular}{|c|c|c|c|c|c|c|}
\hline \multirow{2}{*}{$\begin{array}{c}\text { Altitude } \\
(\mathbf{m})\end{array}$} & \multirow{2}{*}{$\begin{array}{c}\text { Number of } \\
\text { settlements }\end{array}$} & \multirow{2}{*}{$\%$} & \multicolumn{2}{|c|}{1981} & \multicolumn{2}{|c|}{2011} \\
\cline { 4 - 7 } & & Population & $\%$ & Population & $\%$ \\
\hline $401-500$ & 5 & 8.62 & 3,049 & 16.34 & 5.069 & 23,82 \\
\hline $501-600$ & 9 & 15.52 & 3,365 & 18.03 & 8.646 & 40,63 \\
\hline $601-700$ & 4 & 6.89 & 1,076 & 5.77 & 1.009 & 4,74 \\
\hline $701-800$ & 11 & 18.96 & 4,445 & 23.82 & 2.930 & 13,77 \\
\hline $801-900$ & 8 & 13.79 & 1,887 & 10.11 & 1.626 & 7,64 \\
\hline $901-1.000$ & 9 & 15.52 & 3,024 & 16.21 & 1.400 & 6,58 \\
\hline $1.001>$ & 12 & 20.69 & 1,813 & 9.72 & 599 & 2,81 \\
\hline In total & 58 & 100 & 18,659 & 100 & 21.279 & 100,00 \\
\hline
\end{tabular}

Source: Author's calculations

In the studied area of Rogozna, different demographic processes are observed according to the location of settlements regarding the altitude. The highest concentration of the population is in the two lowest altitudes levels (401-600 $\mathrm{m}$ above sea level). Such spatial distribution of the population was influenced by the proximity of municipal centres and main roads. According to the results of the 2011 census, 5,069 inhabitants (23.8\%) lived in the 5 settlements in the lowest hypsometric level (401-500 $\mathrm{m}$ asl.). The second altitude level (501-600 $\mathrm{m} \mathrm{n}$. V.) has 9 settlements with 8,646 inhabitants $(40.6 \%)$. In these two altitude levels, in a relatively short period of 30 years (1981 to 2011), the number of inhabitants more than doubled (it increased from 6,414 to 13,715$)$. The share of the total population of these two levels increased from $34.4 \%$ to $64.5 \%$. The rural settlements which are located above $601 \mathrm{~m}$ are characterized by an intensive depopulation process. The number of inhabitants in 44 settlements which are located above $601 \mathrm{~m}$, was reduced from 12,245 to 7,564 in the period from 1981 to 2011 . The largest number of settlements (12) of this depopulation zone, but also the studied area of Rogozna, is located at altitudes above 1,001 $\mathrm{m}$. These settlements are also in the greatest threat to be completely abandoned (Павловић, 2016).

The rural population of the study area, in the period from 1948 to 2011, increased from 16,073 to 21,279 (for 5,206). However, the population dynamics of the villages of Rogozna can be divided into three periods. The first period was from 1948 to 1961 - when the number of inhabitants increased; 
the second period was from 1961 to 2002 - when variations in population dynamics were expressed; and the third period was from 2002 to 2011 - when the population of rural areas or Rogozna increased again. During the first period, the number of rural population increased by 3,612 (from 16, 073 to 19,685 inhabitants). The increase in the number of inhabitants in this period is expected, as it is a post-war compensation period with increased fertility rates. In addition, regional centers have not yet developed to such an extent secondary functions (primarily the industry), in order to attract the population from the rural areas. In the census period 1961-2002 the total number of inhabitants decreased to 19,615 . However, in this period, the number of inhabitants decreased and increased by about 500 to 1,000 inhabitants (intensive fluctuation in number of inhabitants). Decrease in the number of inhabitants in the rural area has occurred in 1971 and 1981. Such process is understandable because the process of industrialization has taken place in Novi Pazar, Raška and Tutin municipal centers, which also caused intensive migration from the rural areas to the city. The increase in the number of inhabitants was recorded in the 1991 census, while the decrease in population was recorded in the census in 2002. These population changes are understandable when taking into account the processes and events that affected the territory of the former Yugoslavia, during that period. In the third period, the number of inhabitants increased by 1,664 and according to the latest 2011 census, the number of inhabitants is 21,279 . Such processes in the third period are caused by intensive emigration from rural settlements in the mountainous hinterland and the concentration of the rural population in the suburban zones belonging to Rogozna (primarly in the Novi Pazar area).

Table 3 - Number of rural population in the period 1948-2011

\begin{tabular}{|c|c|c|}
\hline Year & Rural population & Index \\
\hline 1948 & 16,073 & - \\
\hline 1953 & 18,008 & 112.04 \\
\hline 1961 & 19,685 & 109.31 \\
\hline 1971 & 18,925 & 96.14 \\
\hline 1981 & 18,659 & 98.60 \\
\hline 1991 & 20,079 & 107.61 \\
\hline 2002 & 19,615 & 97.69 \\
\hline 2011 & 21,279 & 108.48 \\
\hline
\end{tabular}

Source: Републички завод за статистику, 2003; 2012 
One of the most important social problems in Serbia - the decrease of the rural population (depopulation of villages) that exceeds the pace of decreasing the agricultural population (deagrarization) and the total population as a whole, is also noticed in the Rogozna mountain area. The decrease in the number of rural population in Rogozna is evident in most settlements. In Rogozna, 23 settlements (39.7\%) have less than 100 inhabitants: 5 villages have les than 10 inhabitants, 7 villages between 11-20 inhabitants, 5 have between 21-40 inhabitants and 7 have between 61-100 inhabitants. Field research and statistical indicators show that the majority of rural settlements have been affected by the depopulation process.

According to the latest census, no inhabitants are registered in village settlements of Smilov Laz and Brestovo. Based on field surveys in 2014, this data was confirmed - that these villages do not have permanent residents and are demographically extinguished. Negative tendencies regarding the number of inhabitants are also present in the settlements of Coković, Vučja Lokva, Zlatare, Javor and Negotinac, which individually have less than 10 inhabitants. These are villages with older population, with low birth rates and high rates of mortality, and negative natural increase. These settlements, due to the pronounced processes of senilization of the population and devastation of agriculture, do not have a development perspective, and their biological extinguishment is almost inevitable. The most important problem of the village on Rogozna, and therefore the mountain villages in Serbia, is the emigration of a young population. In addition, the key problem is the average age of the population (which in some village is over 60 years). One of the measures of revitalization was that the Government of the Republic of Serbia ordered the urgent construction of the modern road Zubin Potok Novi Pazar. This route was supposed to pass over the mountains region of Rogozna, due to significant reserves of precious metals, which are located in that area. Despite the commencement of works, more than half of the section is still under a macadam. According to the local residents, more than $80 \%$ of the population has left Rogozna due to poverty.

\section{Agriculture as a factor of rural revitalization}

The improvement of economic conditions in the villages of Rogozna, would also led to the better demographic situation in these villages. Local residents believe they would partially revive their closed schools and increase the number of young people in the villages, if they had a safe existence. The 
increase in the number of young population is the basic and most important factor of revitalization, not just the villages on Rogozna, but also in Serbia.

The dominant economic activity in the rural areas of Rogozna is agriculture. As this is a mountainous area, with an average altitude of 800$1.000 \mathrm{~m}$, and the environment conditions for cultivating crops are pore, the agriculture is mostly represented with livestock breeding. Climatic conditions in the middle of the second decade of the 21st century still have a great influence on the activity of the local population. Because of this, livestock breeding is dominant in the Rogozna area, while agriculture is mainly represented in river valleys at the lower altitudes. However, since antiquity, mining has been important part of economic activities in this area, and continued in the age of the medieval Serbian state.

Field research and statistics indicate that agricultural production is decreasing (both crop and livestock production), although there are favourable natural conditions for its development. The best indicator of agricultural aggravation is the degree of utilization of agricultural land and the achieved level of production of fruits, cereals and vegetable plants. Demographic processes (an intensive process of senilization), as well as processes of deagrarization and deruralisation have influenced on such state of agriculture in Rogozna. In addition to these processes, the stagnation of agriculture has been affected by the fragmentation of land, poor implementation of technical measures in agriculture, insufficient financial investment and the underdevelopment of the agricultural social sector.

In addition to improving the quality of the road network and adequate electrification of rural settlements, an important factor of their revitalization, as has already been pointed out, is agriculture. The investment and modernization of crop production and livestock production is an important factor of rural revitalization. The limiting factor for the development of farming for most villages on Rogozna is elevation and relief (as a climatic factor). Hence, the vegetation period is shorter, in relation to the territory of Central Serbia and Vojvodina by 15 days, and in the opinion of some experts, in the higher parts of Rogozna and up to 30 days. Such natural conditions make agricultural products from this area uncompetitive in the Serbian market, and refer them to the local market. The rural population is engaged in agriculture as an additional activity and mainly for its own needs, with small market surpluses. However, field research indicates that in recent years, agriculture has been commercialized in the production of cabbage and other greenhouse vegetable crop production in villages 
which are located at lower altitudes and in river valleys. There are also serious attempts to revitalize livestock production, that is, cattle breeding.

Bearing in mind the natural potential and tradition, cattle breeding in this mountainous area has the best conditions for development. Sheep farming has a long tradition, and the racial composition is mainly represented by Sjenica sheep. Cattle breeding has a long tradition on Rogozna as well (Simmental and Buša breed being the most numerous). The number of cattle in the last decade has dropped significantly. The worrying fact is that about $70 \%$ of household breed cattle only for their own needs. However, field data indicate that there is interest in more intensive farming, especially for cattle breeding.

Fruit production (plum and apple production) has in the past been an important source of income for many villagers in Rogozna. This primarily refers to the production of plums. The areas under this plantation are located on the slopes below the forest zone. However, field research has shown that there are no significant fruit trees today and that fruit is mainly used for their own needs (production of brandy, jam, etc.). In order to improve agricultural production, the Inter-municipal Union of Agricultural Associations was formed in 2007 at the territory of Novi Pazar, Tutin and Sjenica municipality. One of the main goal is to restore agricultural cooperatives that would be an important factor in the revitalization of agriculture.

The nature of the Raška region and rich cultural and historical heritage are a good basis for the development of tourism. However, the tourist potentials of this area are not yet sufficiently known to the public and are not used for tourism purposes. The intensive development of tourism in the Raska region took place in the second half of the 20th century, but was under the restrictive influence of historical, social and economic factors. There was a permanent disparity between the low degree of valorization of natural and anthropogenic tourist values on one side, and the construction of accommodation and catering facilities on the other side (Павловић и Голић, 2011).

One of the factors of the revitalization of the villages of Rogozna is the development of rural tourism. This type of tourism has no tradition in this area. The fragmented and dispersive households, the negative economic and demographic processes in the countryside, the insufficiently developed awareness of the need to preserve the environment and popularizing the city life style are some of the factors that have contributed to the insufficient development of this type of tourism. 


\section{Conclusion}

Bearing in mind the nature of this region, we think that there are conditions for easing migration processes, and therefore revitalization of rural settlements. The main factor for revitalization of the rural areas of Rogozna should be agriculture, and above all animal husbandry (sheep farming and cattle breeding). However, the obtained data indicate that this branch of the economy is at a very low level of development.

Government measures regarding the import and export of milk, dairy products and meat will have negative impact on the agricultural development. In this way, agriculture, and the revitalization of villages in Serbia, will be greatly endangered. It is therefore necessary to realistically look at the situation in our agriculture and the justification of the proposed measures. Vast majority of rural population opposes such measures. They think that our farmers have to be protected, and hence the agriculture will get its role in the economic development of the country. By field research and free assessment, we have come to the conclusion that there are households with sufficiently productive members who can deal with agriculture. These households also have non-agricultural sources of income. The important problem of the villages on Rogozna is also the elderly households inhabited by two members. The characteristic of this category of household is insufficient workforce, as younger family members mostly live in the city and occasionally come to the village.

One of the limiting factors of the rural revitalization is the lack of industrial capacities in the villages of Rogozna (except for the smaller private textile and furniture factories in Trnava and Ribarići, and there are also smaller economic facilities in Kućani and Supnje). The population is mainly sent to work in the city, where the main ind ustrial facilities are located. The limiting factors are obsolete agricultural machinery (average of 25 years and more), lack of irrigation equipment, lack of processing and storage capacities, low prices of agricultural products (primarily vegetables and milk) and poorly organized milk purchase. Mining and reopening of mines is one top the most important ortunities to revive the villages of Rogozna and to overcome poverty.

\section{Acknowledgements}

The paper is the result of the research within the project no. 176008 funded by the Ministry of Education and Science of the Republic of Serbia. 


\section{References}

Buchenrieder, G., Möllers, J., Happe, K., Davidova, S., Fredrikson, L., Baley, A., Gorton, M., Kancs, D. A., Swinnen, J., Vranken, L., Hubbard, C., Ward, N., Juvančič, L., Milczarek, D. and Mishev, P. (2007). Conceptual framework for analysing structural change in agricultural and rural livelihoods. Discussion Paper no. 113, Leibniz Institute of Agricultural Development in Central and Eastern Europe, Halle (Saale), Germany.

Esparcia, J. (2014). Innovation and networks in rural areas: an analysis from European innovative projects. Journal of Rural Studies 34: 1-14.

Galdeano-Gomez, E., Aznar-Sanchez, J. and Perez-Mesa, J. (2010). The complexity of theories on rural development in Europe: an analysis of the paradigmatic case of Almería (South-east Spain). Sociologia Ruralis 51(1): 54-78.

Lowe, P., Murdoch, J. and Ward, N. (1995). Networks in rural development: beyond exogenous and endogenous models. In van der Ploeg, J. D. and van Dijk, G. (eds.): Beyond modernization: the impact of endogenous rural development, Van Gorcum, Assen, 87-105.

Murdoch, J. (2000). Networks - a new paradigm of rural development? Journal of Rural Studies, 16(4): 407-419.

Sobczyk, W. (2014). Sustainable development of rural areas. Problemy ekorozwoju - problems of sustainable development, 9 (1), 119-126.

Павловић, М. (2009). Села Сјеничког краја, антропогеографрска проучавата. Београд: Универзитет у Београду - Географски факултет.

Павловић, М. (2016). Села Рогозне - антропогеографска проучавања. Београд: Универзитет у Београду - Географски факултет.

Павловић, М. и Голић, Р. (2011). Туристички потенцијали Рашке регије и развој сеоског туризма. Гласник српског географског друитва, 91 (3), 39-64.

Павловић, М. и Мишовић С. (2012). Улога Рашке регије у геополитичким процесима Србије. Међународни научни скуп Проблеми и изазови савремене географске науке и наставе. Универзитет у Београду, Географски факултет, 73 - 84, Београд.

Павловић, М., Шабић, Д. и Вујадиновић, С. (2015). Теоријске основе истраживања руралног простора. У Павловић, М., Шабић, Д. и Вујадиновић, С. (ур.): Развојни потенцијали и ограничења ревитализације развоја руралног простора Централне Србије, Географски факултет, Београд, 11-31. 
Петровић, П. Ж. (2010). Рашка, антропогеографрка истраживаға, књига 2. Нови Пазар: Музеј „Рас“.

Ћоровић, В. (ур.) (1928). Списи сb. Саве. Дела старих српских писаца, књига 1. Београд: Српска краљевска академија.

(2003). Попис становништва, домаћинстава и станова у 2002. години. Упоредни преглед броја становника - Књига 9. Републички завод за статистику. Београд.

(2012). Попис становништва, домаћинстава и станова 2011. години. Старост и пол. Подаци по насељима - Књига 2. Републички завод за статистику, Београд.

Општине у Србији 1982, 2002, 2015, Републички завод за статистику, Београд. 